\title{
Vitamin $D$ and manganese in the nutrition of the chick
}

\author{
BY R. HILL \\ Royal Veterinary College, University of London \\ (Received I3 Fuly г966-Accepted 14 March 1967)
}

\begin{abstract}
I. In two experiments with chicks given diets of different manganese content, the effects of vitamin $\mathrm{D}$ on the $\mathrm{Mn}$ contents of bone and liver and on the retention of ${ }^{54} \mathrm{Mn}$ in bone, liver and the whole body were determined.

2. Vitamin D slightly increased the $\mathrm{Mn}$ content of dry fat-free bone but the proportion of $\mathrm{Mn}$ to ash remained unchanged and the $\mathrm{Mn}$ content of bone was influenced much more by the level of dietary $\mathrm{Mn}$ than by the presence of vitamin $\mathrm{D}$.

3. Vitamin $\mathrm{D}$, when given over a 3 -week period, increased slightly the Mn content of the liver, but again the level of dietary $M n$ had a greater effect than the presence of vitamin $D$.

4. The retention of an oral dose of ${ }^{54} \mathrm{Mn}$ was not uniformly influenced by vitamin $\mathrm{D}$, but in birds given the high-Mn diet retention was reduced by vitamin $\mathrm{D}$, indicating a decrease in the turnover of $\mathrm{Mn}$.
\end{abstract}

Although the principal mineral element affected by vitamin D appears to be calcium, positive effects of vitamin $\mathrm{D}$ on absorption or metabolism have been demonstrated for strontium (Greenberg, I945), lead (Sobel \& Burger, 1955), magnesium (Meintzer \& Steenbock, 1955), beryllium, barium, zinc and cadmium (Worker \& Migicovsky, I961 $a, b$ ), cobalt and caesium (Wasserman, 1962) and iron (Masuhara \& Migicovsky, I963).

It has also been suggested that a relationship exists between vitamin $\mathrm{D}$ and manganese (Ministry of Agriculture, Fisheries and Food, I963), a slight deficiency of either being counteracted by a larger intake of the other; this view is encouraged by the association of each with both bone and shell formation (Underwood, I962). The object of the two experiments described here was to study this possible relationship between vitamin $\mathrm{D}$ and $\mathrm{Mn}$ by determining the effect of vitamin $\mathrm{D}$ on the Mn content of bone and liver and on the retention of ${ }^{54} \mathrm{Mn}$, in chicks given diets of different $\mathrm{Mn}$ content.

\section{EXPERIMENTAL}

Expt I. Thirty-six I-day-old chicks were divided at random into six groups each of six birds, and given the following dietary treatments:

\begin{tabular}{cl} 
Group & \multicolumn{1}{c}{ Mn } \\
A & Low (no Mn supplement) \\
B & Low (no Mn supplement) \\
C & Medium (5 $\mu \mathrm{g} \mathrm{Mn} / \mathrm{g}$ added) \\
D & Medium $(5 \mu \mathrm{g} \mathrm{Mn} / \mathrm{g}$ added) \\
E & High $(25 \mu \mathrm{g} \mathrm{Mn} / \mathrm{g}$ added) \\
F & High $(25 \mu \mathrm{g} \mathrm{Mn} / \mathrm{g}$ added)
\end{tabular}

Vitamin D

Low (50 i.u. added/kg diet)

High (500 i.u. added $/ \mathrm{kg}$ diet)

Low (50 i.u. added $/ \mathrm{kg}$ diet)

High (500 i.u. added $/ \mathrm{kg}$ diet)

Low (5o i.u. added $/ \mathrm{kg}$ diet)

High (500 i.u. added $/ \mathrm{kg}$ diet)

The basal diet, composed of purified nutrients, provided more than sufficient of all nutrients, except vitamin $\mathrm{D}$ and $\mathrm{Mn}$, to satisfy the estimate of requirements by the National Research Council (1960) (NRC), and the Agricultural Research Council 
(1963) (ARC). The basal diet contained $5 \mu \mathrm{g} \mathrm{Mn} / \mathrm{g}$; thus the total Mn concentration $(\mu \mathrm{g} / \mathrm{g})$ was 5 for groups $\mathrm{A}$ and $\mathrm{B}$, Io for groups $\mathrm{C}$ and $\mathrm{D}$ and 30 for groups $\mathrm{E}$ and $\mathrm{F}$.

The birds were inspected weekly for evidence of perosis. At 3 weeks of age radiographs of the tibio-tarsal joint revealed marked rachitic lesions in the birds of groups A, $\mathrm{C}$ and $\mathrm{E}$ and all birds were killed at this age. The left femurs and tibias and the livers were dried, extracted with an ethanol-benzene $(2: 1, \mathrm{v} / \mathrm{v})$ mixture and then dried and weighed. The bones were ashed overnight at $600^{\circ}$; weights of ash were obtained and Mn determinations were carried out by the method of Yuen (1958). The dry fatfree livers were ashed and $\mathrm{Mn}$ was determined by the standard permanganate method (Association of Official Agricultural Chemists, I945). The method of Yuen was found unsatisfactory for liver.

Expt 2. Forty-eight I-day-old chicks were divided initially at random into two groups each of twenty-four birds. One group was given a low-Mn diet (no Mn supplement) and the other a high-Mn diet (the same diet with $50 \mu \mathrm{g} \mathrm{Mn} / \mathrm{g}$ added). The basal diet was composed of commonly used feeding-stuffs and contained $7 \mu \mathrm{g} \mathrm{Mn} / \mathrm{g}$ and no added vitamin $\mathrm{D}$, but in all other respects it met the nutrient requirements suggested in the NRC and ARC publications.

At 5 weeks of age the birds of each group (low- and high-Mn diets) were divided into four subgroups, each of six birds, for vitamin $\mathrm{D}$ treatment as follows:

$\begin{array}{cccc}\text { Group } & \text { Mn } & \text { Vitamin } & \begin{array}{c}\text { Duration of } \\ \text { vitamin D } \\ \text { treatment (days) }\end{array} \\ \text { A } & \text { Low } & - & 0 \\ \text { B } & \text { Low } & + & 5 \\ \text { C } & \text { Low } & - & 0 \\ \text { D } & \text { Low } & + & \text { ro } \\ \text { E } & \text { High } & - & 0 \\ \text { F } & \text { High } & + & 5 \\ \text { G } & \text { High } & - & 0 \\ \text { H } & \text { High } & + & \text { I0 }\end{array}$

Those treated with vitamin D were given a dose of 1000 i.u. and then the low- or high-Mn diet containing 600 i.u./kg added vitamin D until they were killed 5 or to days later.

The allocation to vitamin $D$ treatments at 5 weeks was made after measurement on radiographs of the tibio-metatarsal distance. Treatment groups were balanced by a randomized block scheme with respect to this assessment of the degree of rickets. This procedure was followed because there was greater variability among birds in this experiment than in the first; also the rachitic lesions were less marked than in Expt 1 . Observations were made weekly for clinical evidence of perosis. Each bird was given, $24 \mathrm{~h}$ before it was killed, an oral dose of about $0.3 \mu \mathrm{c}{ }^{54} \mathrm{Mn}$ ( 100000 counts/min) as the chloride in $0.8 \mathrm{ml}$ solution pipetted into the crop. When the birds were killed, blood samples were taken, the digestive tract was washed free of contents and the liver and left tibia were removed. The ash content of the tibia and the $\mathrm{Mn}$ contents of tibia and liver were determined as in Expt $\mathrm{I}$, and determinations of ${ }^{54} \mathrm{Mn}$ in blood, liver, tibia ash, and ash of the remaining carcass were made in the manner described by Hill $(1965 a)$. 
RESULTS

The detailed results are given in the tables but in describing them attention is confined largely to the main effects of vitamin $\mathrm{D}$ on $\mathrm{Mn}$ and ${ }^{54} \mathrm{Mn}$ of the tissues and on significant interactions between the levels of dietary $\mathrm{Mn}$ and vitamin D.

Expt I. No cases of perosis were observed among these birds, which were killed at 3 weeks of age.

Mean bone weights, percentages of ash, and Mn concentrations in femurs, tibias and livers, together with the results of statistical analyses, are given in Table $\mathbf{~}$. Bone weights and percentages of ash are given primarily to provide confirmation of a vitamin $\mathrm{D}$ deficiency in groups $\mathrm{A}, \mathrm{C}$ and $\mathrm{E}$. These values were not affected by the level of dietary $\mathrm{Mn}$ but were increased markedly by vitamin $\mathrm{D}$. The Mn content of dry fat-free bone was significantly increased by vitamin $\mathrm{D}$ in both femur (from 2.23 to 2.84 ) and tibia (from I. 5 I to $2.34 \mu \mathrm{g} / \mathrm{g}$ ), but in neither bone did vitamin D increase the $\mathrm{Mn}$ content when expressed as a concentration of ash. Thus the effect of vitamin D was to increase the total weight of bone and increase the concentrations of ash and $\mathrm{Mn}$ in bone, but not to increase the proportion of $\mathrm{Mn}$ to ash. The $\mathrm{Mn}$ content of the liver was increased by vitamin $\mathrm{D}$ and the increase just reached significance.

The level of dietary Mn affected significantly the Mn content of bones and liver but there was no suggestion of an interaction between dietary levels of Mn and vita$\min \mathrm{D}$.

Expt 2. There were three cases of perosis in birds given the low-Mn diet; these occurred before vitamin $D$ treatment began and there was no obvious change afterwards.

The quantity of ${ }^{54} \mathrm{Mn}$ in all samples of blood was very small, too small to be determined accurately.

Mean bone weights and percentages of ash of the tibia, Mn concentrations in tibia and liver, and ${ }^{54} \mathrm{Mn}$ counts for tibia, liver and the whole bird are given in Table 2, with the results of the statistical analyses. There were significant main effects of vitamin $\mathrm{D}$ on bone weight and percentage of ash that increased with time of vitamin $\mathrm{D}$ treatment. Vitamin D did not significantly increase the Mn content of bone, though the difference between means calculated as a concentration of dry fat-free bone approached significance and, as in Expt I, was greater than that calculated on an ash basis. There was no main effect of vitamin D on the Mn content of the liver.

The ${ }^{54} \mathrm{Mn}$ contents of tibia, liver and whole bird, and the specific activities of tibia and liver were not affected uniformly by vitamin $D$, but there was a tendency for ${ }^{54} \mathrm{Mn}$ content to be slightly elevated by vitamin $\mathrm{D}$ in birds given the low-Mn diet and depressed, in some cases quite markedly, by vitamin $\mathrm{D}$ in birds given the high-Mn diet (groups $\mathrm{E} v . \mathrm{F}$ and $\mathrm{G} v, \mathrm{H}$ ); these differences gave significant interactions $(\mathrm{Mn} \times$ vitamin D) for the tibia and for the whole bird. The most consistent effect of vitamin $\mathrm{D}$ on ${ }^{54} \mathrm{Mn}$ was to cause a decrease in retention of ${ }^{54} \mathrm{Mn}$ in the tissues of birds given the high-Mn diet, an effect that increased with time (groups $(\mathrm{F} / \mathrm{E})>(\mathrm{H} / \mathrm{G})$ ), and was largely responsible for the interaction between vitamin $\mathrm{D}$ and the ${ }^{54} \mathrm{Mn}$ content of dry fat-free tibia $(P<0.05)$. 


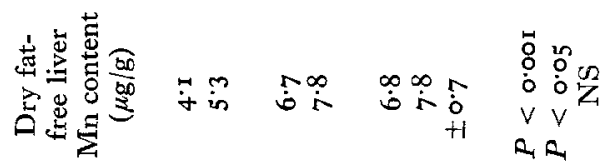

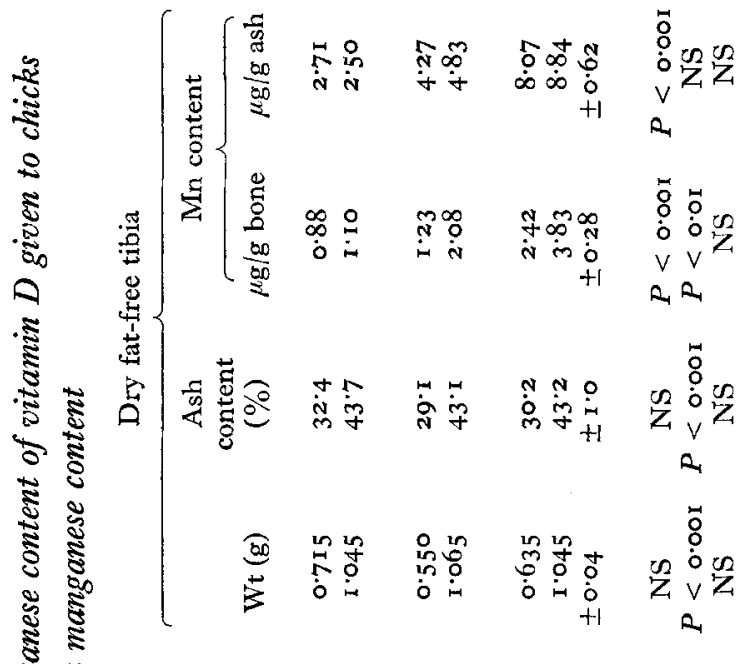

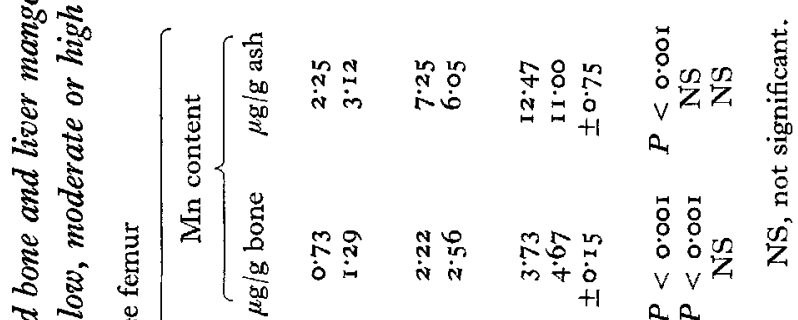

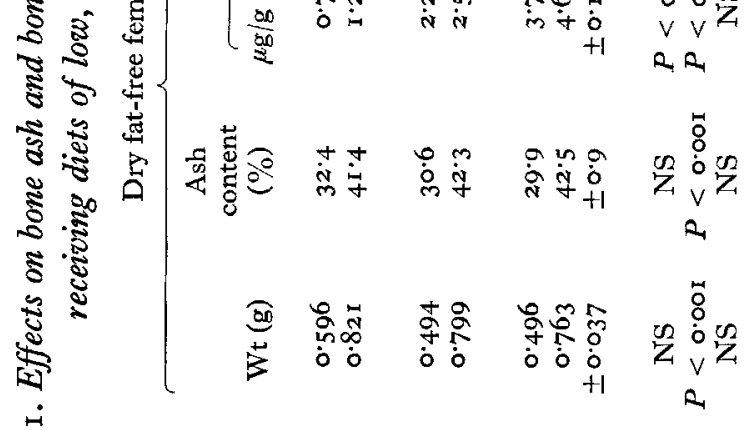

藏

递

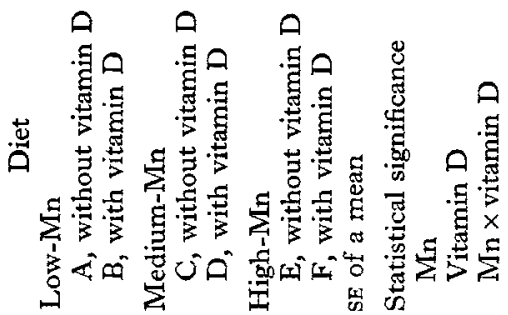


Vol. 21

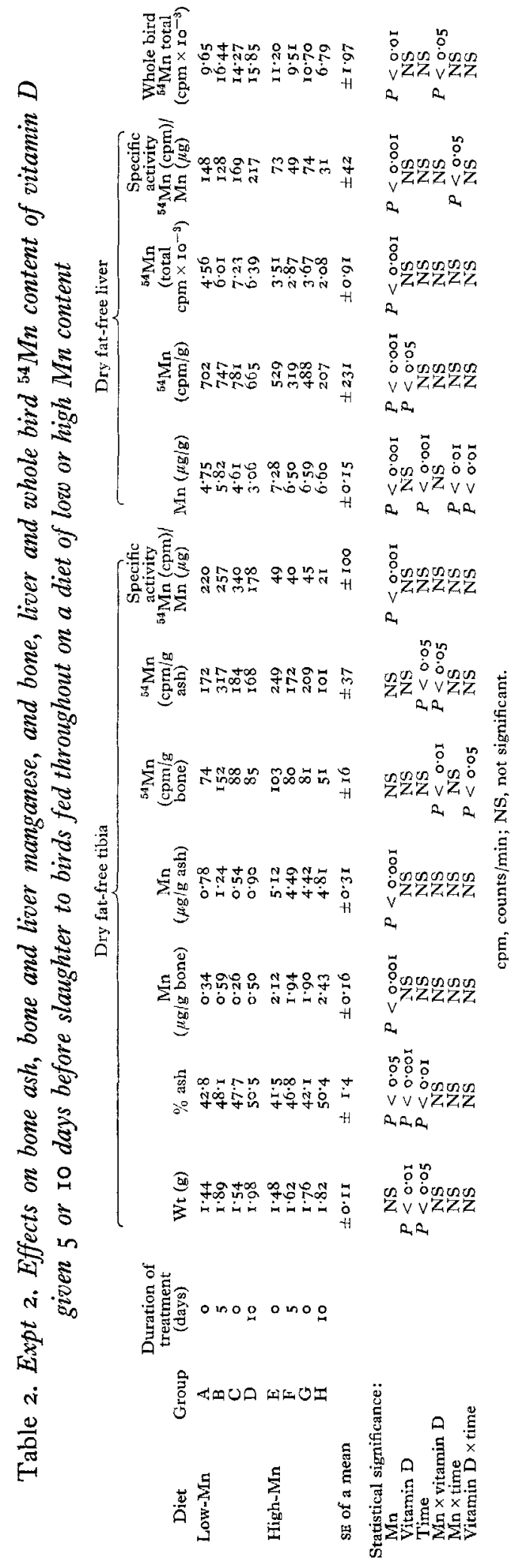




\section{DISCUSSION}

From the results of these experiments it is concluded that vitamin $\mathrm{D}$ does not have a large specific effect on the retention and metabolism of $\mathrm{Mn}$ in the chick. The increase in the Mn content of bone caused by vitamin $\mathrm{D}$ always closely paralleled an increase in ash content and, in view of the close association demonstrated between Mn and the mineral conponent of bone (Hill, $\mathrm{r}_{96} 6 \mathrm{~b}$ ), the observed increase in the Mn content of dry fat-free bone was probably secondary to an effect on the degree of mineralization. It is also evident from the results of these experiments that a shortage of vitamin $D$, sufficient to produce a rachitic state, did not prevent Mn from reaching the bone. The Mn contents of the bones of rachitic chicks given the high-Mn diets were much greater in both experiments than those of the bones of non-rachitic chicks given vitamin $D$ and the low-Mn diets. A similar situation was found with the liver; that is, the level of dietary $\mathrm{Mn}$ influenced the Mn content of the tissues much more than the presence of vitamin $\mathrm{D}$.

From the almost zero values obtained for the ${ }^{54} \mathrm{Mn}$ content of blood it is evident that, as in the adult bird (Hill, I965a), very large doses (about $20 \mu \mathrm{c} /$ bird) of radioactive $\mathrm{Mn}$ must be given if reliable counts are to be obtained.

As noted above, in birds given the high-Mn diet the retention of ${ }^{54} \mathrm{Mn}$ was reduced by vitamin $\mathrm{D}$, but there was no indication that this was leading or would lead to a decrease in total Mn content of the tissue; thus it is concluded that vitamin D reduced the turnover of $\mathrm{Mn}$.

The able assistance of Mrs Ann Hosier is gratefully acknowledged.

\section{REFERENCES}

Agricultural Research Council (1963). The Nutrient Requirements of Farm Livestock. No. I, Poultry. London: Agricultural Research Council.

Association of Official Agricultural Chemists (1945). Official and Tentative Methods of Analysis, 6th ed., p. I 20. Washington D.C.: Association of Official Agricultural Chemists.

Greenberg, D. M. (1945). F. biol. Chem. 157, 99.

Hill, R. (1965a). Br. F. Nutr. 19, I7I.

Hill, R. ( $965 b)$. Br. $\%$. Nutr. I9, I63.

Masuhara, T. \& Migicovsky, B. B. (1963). F. Nutr. 80, 332.

Meintzer, R. B. \& Steenbock, H. (1955). F. Nutr. 56, 285 .

Ministry of Agriculture Fisheries and Food ( 1963$)$. Bull. Minist. Agric. Fish. Fd, Lond. no. 174.

National Research Council (1960). Publs natn. Res. Coun., Wash. no. 827.

Sobel, A. E. \& Burger, M. (1955). F. biol. Chem. 212, 105.

Underwood, E. J. (1962). Trace Elements in Human and Animal Nutrition, and ed., ch. 7. London: Academic Press Inc.

Wasserman, R. H. ( ( 962). F. Nutr. 77, 69.

Worker, N. A. \& Migicovsky, B. B. (I96ra). F. Nutr. 74, 490.

Worker, N. A. \& Migicovsky, B. B. ( I 96 I $b$ ). F. Nutr. 75, 222.

Yuen, S. H. (1958). Analyst, Lond. 83, 350 . 